\title{
Effect of Zinc and Silicon on Growth and Yield of Aromatic Rice (Oryza Sativa) in North-Western Plains of India
}

\author{
Veer Singh, Virendra Singh*, Satybhan Singh and Richa Khanna
}

School of Agricultural Sciences \& Engineering, IFTM University, India

\begin{abstract}
The present study entitled Effect of Zinc and silicon on growth and yield of aromatic rice in north western plain zone of India was carried out during kharif 2018 at Student Instructional Cum-Research Farm, IFTM University, Moradabad, India. The ten treatment combinations (viz. $T_{1}$ Control, $T_{2}$ RDF 120:80:40, T RDF 120:80:40 + Two Zinc spray @ 0.5\%, T RDF 120:80:40 + Two Si spray @ 0.2\%, T 5 RDF 120:80:40 + Two Si spray @ 0.3\%, T 6 - NPK 150:80:40, T 7 NPK 150:80:40 + Two Zinc spray @ 0.5\%, T. NPK 150:80:40 + Two Si spray @ 0.2\%, T. NPK 150:80:40 + Two Si spray @ 0.3\%) were tested under randomized block design with three replications. The results revealed that the application of zinc and silicon significantly influenced the growth and yield of aromatic rice. Plant height, LAl, dry weight, number of tillers, panicle length, number of grains per panicle and 1000-grain weight were recorded maximum with the application of 120:80:40 kg ha- ${ }^{-1} \mathrm{NPK}+@$ $0.5 \% \mathrm{Zn}$ spray at 30 and 45 DAT. Grain yield and harvest index also influenced significantly with the application of zinc and silicon and maximum grain yield was recorded with the application of 150:80:40 NPK + two Zn spray 0.5\% (65.88 q $\mathrm{ha}^{-1}$ ) followed by treatment 150:80:40 NPK + Two Si spray @ 0.3\% (63.46 q ha-1) and lowest in $\mathrm{T}_{1}$ control (30.12 q ha $\left.\mathrm{q}^{-1}\right)$. Harvest index was recorded non-significant.
\end{abstract}

\section{Keywords}

Zinc, Silicon, Aromatic rice

\section{Introduction}

Rice (Oryza sativa L.) is one of the most important field crops after wheat in the world providing staple food to the millions. It is an indispensable source of calories for almost half of the population with in Asia. More than $90 \%$ of the world rice is produced and consumed in Asia, which is a native for $60 \%$ of the earth's population. Rice is the first most important crop in India where it is grown in an area of 43.79 million ha ${ }^{-1}$ with a total production of 112.91 million tones and an average productivity of $2578 \mathrm{~kg} \mathrm{ha}^{-1}$ [1]. India is first in terms of area (44.5 million ha) and second in production (172.58 million tonnes) [2]. Basmati rice is primarily grown in north-western India and Pakistan. These rice cultivars are preferred for their long and slender kernels, which expand to 3-4 times their original length and remain fluffy on cooking. Paddy soils are usually deficient in organic matter because of high temperature and moisture, which causes rapid decomposition of organic matter [3]. Aromatic rice constitutes a small but special group of rice, which is considered best for aroma, superfine grain and better cooking qualities [4]. There are many known groups of aromatic varieties such as Basmati rice from India and Pakistan and Jasmine rice from Thailand. These groups and varieties differ in the grain length, shape, weight, density and in their cooking and eating quality. Aromatic rice has occupied a prime position in society for aroma, milling, cooking and eating qualities and has been considered auspicious [5].

In India, zinc is considered as the fourth important yield limiting nutrient after nitrogen, phosphorus and potassium respectively [6]. The critical limit of available zinc in the soil suitable for rice growth is $0.6 \mathrm{mg} \mathrm{kg}^{-1}$. Soil application of zinc increased the grain yield and foliar application of zinc increase the grain zinc concentration [7]. When rice was grown in different types of soil, up to 90 percent difference was observed in the grain $\mathrm{Zn}$ concentration in the same rice varieties [8]. Silicon is an important micronutrient for healthy and competitive growth of all cereals including rice in Asia [9]. Rice is one of highly sensitive crops to Zn deficiency and Zn limits growth and yield of rice. Zinc deficiency in rice has been widely reported in many rice-growing regions of the world. In India 47

*Corresponding author: Virendra Singh, School of Agricultural Sciences \& Engineering, IFTM University, Moradabad (U.P.)-244 102 , India

Accepted: July 02, 2020

Published online: July 04, 2020

Citation: Singh V, Singh V, Singh S, et al. (2020) Effect of Zinc and Silicon on Growth and Yield of Aromatic Rice (Oryza Sativa) in North-Western Plains of India. J Rice Res Dev 3(1):82-86 
percent and in MP 60.3 percent of the soils found deficient in $\mathrm{Zn}[10]$. Paddy soil conditions are usually not favorable for the availability of zinc and hence zinc deficiency has been reported countrywide in rice soils [11].

Role of silicon in plant health and growth has been investigated in silicon accumulating crops and it seemed significantly effecting [12]. Research evidences proved that adequate uptake of silicon ( $\mathrm{Si}$ ) can increase the tolerance of agronomic crops especially rice to both abiotic and biotic stress [13]. Effects of silicon on yield are related to the deposition of the element under the leaf epidermis which results a physical mechanism of defense, reduces lodging, increases photosynthesis capacity and decreases transpiration losses [14]. Silicon (Si) is the second most abundant element in the earth's crust and considered as a beneficial element for crop growth, especially for crops under poaceae family. Rice is a typical silicon accumulating plant and it benefits from silicon nutrition. Its supply is essential for healthy growth and economic yield of the rice crop. Silicon interacts favorably with other applied nutrients and improves their agronomic performance and efficiency in terms of yield response. Also, it improves the tolerance of rice plants to abiotic and biotic stresses. Hence, silicon management is essential for increasing and sustaining rice productivity [15]. Accumulation of $\mathrm{Si}$ in leaves and tissues in addition to conferring resistance against fungal diseases and insect pests, can improve erectness of leaves, increase yield and alleviate water stress, salinity stress and nutrient deficiency or toxicity stresses as well. Silicon is also considered as an environmentally-friendly element in relation to soils, fertilizers and plant nutrition [13]. In modern agriculture, $\mathrm{Si}$ has already been recognized as a functional nutrient for a number of crops, particularly rice and sugarcane, and plays an important role in the growth and development of crops, especially gramineae crops $[16,17]$. The hulls of poor-quality and milky-white grains (kernels) are generally low in silicon content, which is directly proportional to the silicon concentration in the rice straw $[18,19]$.

\section{Materials and Methods}

Present field experiment was conducted during kharif 2018 at Student Instructional Cum-Research Farm, IFTM University, Moradabad, India. The experimental site lies between $28^{\circ} 21^{\prime}$ to $28^{\circ} 16^{\prime}$ North latitude and $78^{\circ} 4^{\prime}$ to $79^{\circ}$ East longitude and mean sea level of 193 meters. The soil samples were collected randomly to analyze the physico-chemical properties from different spots on the experimental site at the depth of 0-15 $\mathrm{cm}$ before conducting the experiment and a composite soil sample was prepared after proper drying, mixing and sieving. The soil of the experimental site was sandy loam in texture, having $7.8 \mathrm{pH}$ with 0.43 per cent of organic carbon, EC 0.8 and available nitrogen is low (96.75 kgha-1), available phosphorus was medium (22.5 kg ha-1) and available potassium was medium ( $\left.225 \mathrm{~kg} \mathrm{ha}^{-1}\right)$ and micronutrients were available Sulphur 9.60 ppm, Zn 0.54 ppm, B 0.45 ppm, Fe 4.32 ppm, Mn 5.49 ppm and Cu 0.86 ppm. The experiment consisted of nine treatment combinations viz. ( $\mathrm{T}_{1}$ control, $\mathrm{T}_{2}$ 120:80:40 RDF, T 120:80:40 RDF + Two Zn spray @ 0.5\%, T 120:80:40 + Two Si spray @ 0.2\%, T. 120:80:40 RDF + Two Si spray @ 0.3\%, T 6 150:80:40 NPK, T 150:80:40 NPK + Two Zn spray @ 0.5\%, T 150:80:40 NPK + Two Si spray @ 0.2\% and $\mathrm{T}_{9}$ 150:80:40 NPK + Two Si spray @ 0.3\% which were tested in randomized block design and replicated three times. Foliar application of zinc and silicon were applied at 30 and 45 DAT as per the treatment. The graded levels of NPK were applied through Urea, Single super phosphate and Murate of potash. Half dose of nitrogen and full doses of phosphorus and potassium were applied basally at the time of transplanting. Healthy plant of paddy cultivar Navya (IMR 002) were transplanted at $20 \mathrm{~cm} \times 15 \mathrm{~cm}$ and at a depth of $2-3 \mathrm{~cm}$ on $9^{\text {th }}$ July, 2018. Observations on growth and yield attributes were recorded from five selected plants from the net plots. All the data obtained from the experiment were analyzed statistically using the F-test as per the standard statistical procedure [20] and least significant difference (LSD) values (P0.05) were used to determine the significance of difference between treatment means.

\section{Results and Discussion}

\section{Growth and yield attributes}

Plant height was significantly influenced with the application of zinc and silicon with recommended dose of NPK. Tallest plants were recorded with the application of NPK 120:80:40 kg ha-1 + @ 0.5\% Zn spray at 30 and 45 DAT (Table 1) followed by NPK 150:80:40 + Two Zinc spray @ 0.5\% and NPK 150:80:40. Shortest plant was observed in control treatment. LAl of aromatic rice was recorded maximum (8.05) with the application of treatment T,150:80:40 NPK + two Zn spray $0.5 \%$ at 30 and 45 DAT. Minimum LAI was recorded in control treatment. Dry weight of aromatic rice was influenced significantly with the application of zinc and silicon. Maximum dry weight with was recorded with the application of $\mathrm{T}_{7}$ 150:80:40 $\mathrm{NPK}+$ two Zn spray @ 0.5\% at 30 and 45 DAT (51.44 g) and minimum dry weight was recorded in control treatment. It may be due to the application of RDF with zinc or silicon, which increase the availability of nutrients and silicon also increase the water use efficiency of rice and it also increase the chlorophyll content and resulted the maximum production of photosynthates. The present findings were quite similar with those of Shivay, et al., Metwally, and Pooniya, et al. [21-23].

Number of tillers, number of grains panicle ${ }^{-1}$, weight of grain panicle ${ }^{-1}$, and grain sterility percentage was influenced significantly with the application of zinc and silicon with RDF. Maximum number of tillers plant ${ }^{-1}$ (11.11) was recorded with the application of $\mathrm{T}_{7} 150: 80: 40$ NPK + two Zn spray @ 0.5\% at 30 and 45 DAT (Table 2) while minimum recorded in control plot. Increase in number of tillers by $\mathrm{Zn}$ application may be attributed to its role in various $Z n$ induced enzymatic activity and auxin metabolism which control growth of plant. These results are confirmatory with the findings of Ghani, et al. [24]. Highest number of grain panicle ${ }^{-1}(187.56)$ was recorded with the application of $\mathrm{T}_{9} 150: 80: 40$ NPK + two Si spray @ 0.3\% at 30 and 45 DAT and recorded minimum in control treatment. The efficiency of Si application in increasing the assimilation of carbohydrates in panicles, which leads to increased number of filled grains also reported by Jawahar, et al. [25]. An increasing trend of 1000- seed weight was recorded maximum 
Citation: Singh V, Singh V, Singh S, et al. (2020) Effect of Zinc and Silicon on Growth and Yield of Aromatic Rice (Oryza Sativa) in North-Western Plains of India. J Rice Res Dev 3(1):82-86

Table 1: Plant height $(\mathrm{cm})$, leaf area index and dry weight $(\mathrm{g})$ of aromatic rice as influenced by Zinc and Silicon.

\begin{tabular}{|c|c|c|c|}
\hline Treatments & Plant height $(\mathrm{cm})$ (60DAT) & Leaf are index (60DAT) & Dry weight (g) (60DAT) \\
\hline $\mathrm{T}_{1}$ Control & 104.22 & 4.41 & 30.54 \\
\hline $\mathbf{T}_{2 .}$ RDF 120:80:40 & 129.56 & 7.10 & 37.14 \\
\hline $\mathbf{T}_{3 .}$ RDF 120:80:40 + Two Zinc spray @ 0.5\% & 133.22 & 6.74 & 51.40 \\
\hline $\mathbf{T}_{4-}$ RDF 120:80:40 + Two Si spray @ 0.2\% & 127.44 & 7.20 & 46.51 \\
\hline $\mathbf{T}_{5-}$ RDF 120:80:40 + Two Si spray @ 0.3\% & 128.71 & 7.53 & 46.37 \\
\hline $\mathbf{T}_{6-}$ NPK 150:80:40 & 129.11 & 8.29 & 39.30 \\
\hline $\mathbf{T}_{7 .}$ NPK 150:80:40 + Two Zinc spray @ 0.5\% & 131.92 & 8.05 & 51.44 \\
\hline $\mathbf{T}_{8-}$ NPK 150:80:40 + Two Si spray @ 0.2\% & 132.22 & 8.98 & 42.33 \\
\hline $\mathbf{T}_{9_{-}}$NPK 150:80:40 + Two Si spray @ 0.3\% & 132.67 & 6.87 & 44.86 \\
\hline SE $(m \pm)$ & 2.18 & 0.24 & 2.13 \\
\hline $\mathrm{CD}$ at $5 \%$ & 6.58 & 0.74 & 6.46 \\
\hline
\end{tabular}

Table 2: Effect of application of Zinc and Silicon on the growth and yield attributes of rice.

\begin{tabular}{|c|c|c|c|c|c|c|}
\hline Treatment & $\begin{array}{l}\text { No. of } \\
\text { tillers } \\
\text { plant }^{-1}\end{array}$ & $\begin{array}{l}\text { No. of } \\
\text { effective tillers } \\
\text { plant }^{-1}\end{array}$ & $\begin{array}{l}\text { Number } \\
\text { of grains } \\
\text { Panicle }^{-1}\end{array}$ & $\begin{array}{l}1000 \text { seed } \\
\text { weight (g) }\end{array}$ & $\begin{array}{l}\text { Grain } \\
\text { sterility (\%) }\end{array}$ & $\begin{array}{l}\text { Weight of } \\
\text { grain panicle }{ }^{-1} \\
\text { (g) }\end{array}$ \\
\hline $\mathrm{T}_{1}$ Control & 5.56 & 3.67 & 132.11 & 27.69 & 22.76 & 3.44 \\
\hline $\mathbf{T}_{2}$ RDF $120: 80: 40$ & 10.11 & 7.33 & 176.22 & 31.25 & 18.69 & 4.29 \\
\hline $\mathbf{T}_{3-}$ RDF 120:80:40 + Two Zinc spray @ 0.5\%/lit & 10.78 & 8.33 & 183.00 & 30.87 & 13.35 & 4.21 \\
\hline $\mathbf{T}_{4}$ RDF 120:80:40 + Two Si spray @ 2 ml/lit & 10.00 & 8.22 & 179.11 & 31.41 & 16.37 & 4.42 \\
\hline $\mathbf{T}_{5-}$ RDF 120:80:40 + Two Si spray @ 3 ml/lit & 10.11 & 7.99 & 180.11 & 30.70 & 16.03 & 4.72 \\
\hline $\mathbf{T}_{6-}$ NPK 150:80:40 & 9.22 & 7.89 & 181.33 & 30.71 & 17.95 & 4.69 \\
\hline $\mathbf{T}_{7-}$ NPK 150:80:40 + Two Zinc spray @ 0.5\%/lit & 11.11 & 8.56 & 180.44 & 32.77 & 17.29 & 4.35 \\
\hline $\mathbf{T}_{8-}$ NPK 150:80:40 + Two Si spray @ 2 ml/lit & 8.99 & 7.99 & 180.67 & 31.22 & 18.12 & 4.83 \\
\hline $\mathbf{T}_{9 .}$ NPK 150:80:40 + Two Si spray @ 3 ml/lit & 10.67 & 8.34 & 187.56 & 30.76 & 18.36 & 5.49 \\
\hline SE $(m \pm)$ & 0.47 & 0.33 & 6.05 & 0.53 & 1.51 & 0.21 \\
\hline CD at $5 \%$ & 1.41 & 1.02 & 18.31 & 1.61 & 4.59 & 0.63 \\
\hline
\end{tabular}

Table 3: Yield and harvest index of aromatic rice as influenced by Zinc and Silicon.

\begin{tabular}{|c|c|c|c|c|}
\hline Treatments & Grain yield $\left(q\right.$ ha $\left.^{-1}\right)$ & Stover yield $\left(\mathbf{q ~ h a}{ }^{1}\right)$ & Biological yield (q ha ${ }^{-1}$ ) & Harvest index (\%) \\
\hline $\mathrm{T}_{1}$ Control & 30.12 & 42.31 & 72.44 & 41.59 \\
\hline $\mathbf{T}_{2-}$ RDF 120:80:40 & 52.06 & 62.28 & 114.34 & 45.53 \\
\hline $\mathbf{T}_{3-}$ RDF 120:80:40 + Two Zinc spray @ 0.5\%/lit & 59.14 & 63.87 & 126.67 & 46.83 \\
\hline $\mathbf{T}_{4-}$ RDF 120:80:40 + Two Si spray @ 2 ml/lit & 53.04 & 65.98 & 119.02 & 44.59 \\
\hline $\mathbf{T}_{5-}$ RDF 120:80:40 + Two Si spray @ 3 ml/lit & 54.72 & 68.22 & 122.96 & 44.50 \\
\hline $\mathbf{T}_{6-}$ NPK 150:80:40 & 62.42 & 72.67 & 135.09 & 46.28 \\
\hline $\mathbf{T}_{7-}$ NPK 150:80:40 + Two Zinc spray @ 0.5\%/lit & 65.88 & 73.28 & 139.16 & 47.32 \\
\hline $\mathbf{T}_{8-}$ NPK 150:80:40 + Two Si spray @ 2 ml/lit & 62.86 & 78.23 & 141.09 & 44.53 \\
\hline $\mathbf{T}_{9-}$ NPK 150:80:40 + Two Si spray @ 3 ml/lit & 63.46 & 75.79 & 139.23 & 45.60 \\
\hline $\mathrm{SE}(\mathrm{m} \pm)$ & 1.76 & 2.570 & 3.978 & 1.000 \\
\hline CD at $5 \%$ & 5.308 & 7.772 & 11.998 & 3.024 \\
\hline
\end{tabular}

with the application of $\mathrm{T}_{7}$ 150:80:40 NPK + two Zn spray 0.5\% at 30 and 45 DAT. Grain sterility (\%) of aromatic rice was recorded the application maximum with of $\mathrm{T}_{3}$ 120:80:40 NPK + two Zn spray @ 0.5\% at 30 and 45 DAT(22.76\%) and minimum
(13.35\%) in treatment $T_{3-}$ RDF 120:80:40 + Two Zinc spray @ $0.5 \%$ at 30 and 45 DAT. Weight of grain panicle ${ }^{-1}$ was recorded maximum in $\mathrm{T}_{9}$ 150:80:40 NPK + two Si spray 0.3\% @ at 30 and 45 DAT (5.49 g) followed by $\mathrm{T}_{8-}$ NPK 150:80:40 + Two Si 
Citation: Singh V, Singh V, Singh S, et al. (2020) Effect of Zinc and Silicon on Growth and Yield of Aromatic Rice (Oryza Sativa) in North-Western Plains of India. J Rice Res Dev 3(1):82-86

spray @ $0.2 \%$ at 30 and 45 DAT. Similar observations were also reported earlier by Singh and Shivay, and Salton, et al. $[26,27]$.

\section{Yield}

Grain yield of aromatic rice was significantly influenced with the application of zinc and silicon with NPK (Table 3). The highest grain yield was recorded under treatment $\mathrm{T}_{7}$ 150:80:40 NPK + two Zn spray 0.5\% (65.88 q ha-1) followed by treatment $T_{9 .}$ NPK 150:80:40 + Two Si spray @ 0.3\% (63.46 q $\mathrm{ha}^{-1}$ ) and lowest in $\mathrm{T}_{1}$ control (30.12 q ha-1). Supply of $\mathrm{Zn}$ by foliar sprays might have made adequate availability of $\mathrm{Zn}$ which has facilitated the growth of the plant, due to its involvement in many metallic enzyme system, regulatory functions and auxin production [28], increased synthesis and transport of carbohydrates to the sink $[29,30]$. Straw and biological yield was significantly influenced by the application of treatment $\mathrm{T}_{8}$ 150:80:40 two Si spray 0.2\% (78.23 and $141.09 \mathrm{q} \mathrm{ha}^{-1}$ ). Minimum straw and biological yield were recorded from $T_{1}$ control (42.31 and $72.44 \mathrm{q} \mathrm{ha}^{-1}$, respectively). Harvest index was recorded non-significant. Similar results were also earlier reported by Ghasal, et al. and Yadav, et al. [31,32].

\section{Conclusion}

On the basis of experimental findings, it can be concluded that application of 150:80:40 $\mathrm{kg} \mathrm{ha}^{-1}$ with two $\mathrm{Zn}$ foliar spray at 30 and 45 days after transplanting improved the yield attributes of rice.

\section{References}

1. Anonymous (2018) Agricultural statistics at a glance 2018. Directorate of Economics and Statistics, Department of Agriculture and Cooperation, Ministry of Agriculture, Government of India, New Delhi

2. FAO (2018) FAOSTAT production statistics. Food and Agriculture Organization. Rome, Italy.

3. Mohammad A, Hamad RJ, Khan EA, et al. (2005) Comparative response of diverse rice varieties to green manuring (Sesbaniaaculeata). Journal of Research (Science) 16: 39-43.

4. Nene YL (1998) Basmati rice: A distinct variety (cultivar) of the Indian subcontinent. Asian Agri-History 2: 178-188.

5. Ahuja SC, Panwar DVS, Ahuja Uma, et al. (1995) Basmati RiceThe Scented pearl, CCS Haryana Agricultural University, Hisar, Haryana, India, 53.

6. Singh Virendra, Singh Satybhan (2019) Organic rice production technology. Research Trends in Agriculture AkiNik Publications, New Delhi, 16: 99-129.

7. Yerokun AO, Chirwa M (2014) Soil and foliar application to maize and wheat grown on a Zambian Alfisol. African Journal of Agricultural Research 9: 963-970.

8. Graham RD, Senadhira D, Beebe S, et al. (1999) Breeding for micronutrient density in edible portions of staple food crops: Conventional approaches. Field Crops Research 60: 57-80.

9. Brunings AM, LE Datnoff, JF Ma, et al. (2009) Differential gene expression of rice in response to silicon and rice blast fungus Magnaporthe oryzae. Ann Appl Biol 155: 161-170.

10. Shukla AK, Tiwari PK (2014) Micro and secondary nutrients and pollutant elements research in India. Progress report- 20112013.

11. Bhatti HM, M Rashid (1985) Micronutrient research in Pakistanpp. Proc Rice Prod, 67-72.

12. Jinab H, Solond M, Varietel M (2010) Functional food product development. Pub Smith \& Charter.

13. Ma JF, Takahashi E (2002) Soil fertilizer and plant silicon research in Japan. Elsevier Science, Amsterdam.

14. Korndorfer GH, Pereira HS, Nolla A (2004) Silicon analysis in soil, plant and fertilizers. Brazil.

15. Rao GB, Poornima Yadav, Elizabeth K Syriac (2017) Silicon nutrition in rice: A review. Pharmacognosy Journal 6: 390-392.

16. Epstein E (1999) Silicon. Annu Rev Plant Physiol Plant Mol Biol 50: 641-664.

17. Hodson MJ, White PJ, Mead A, et al. (2005) Phylogenetic variation in the silicon composition of plants. Annals of Botany 96: 1027-1046.

18. ND Yogendra, BH Kumara, N Chandrashekar, et al. (2014) Effect of silicon on real time nitrogen management in a rice ecosystem. African Journal of Agricultural Research 9: 831-840.

19. Aleshin EP, Aleshin NE, Avakian AR (1978) The effect of various nutrition and gibberillins on $\mathrm{SiO}_{2}$ content in hulls of rice. Agrochemistry 7: 64-68.

20. Gomez KA, Gomez AA (1984) Statistical Procedures for Agricultural Research. ( $2^{\text {nd }}$ edn), Wiley-Inter-Science publication, John Wiley and Sons, New York, USA.

21. Shivay, YS Kumar, D Prasad, et al. (2008) Relative yield and zinc uptake by rice from zinc sulphate and zinc oxide coating onto urea. Nutrient Cycling in Agroecosystems 80: 181-188.

22. Metwally TF (2011) Performance of Egyptian hybrid rice under different rates, time and methods of zinc application. Journal of Agricultural Research 37: 642-657.

23. Pooniya V, Shivay, YS, et al. (2012) Zinc fertilization in conjunction with green manuring on productivity and nutrient uptake in basmati rice. Indian Journal of Fertilizers 8: 54-58.

24. Ghani A, Shah M, Khan, et al. (1990) Response of rice to elevated rates of zinc in mountainous areas of Swat. Sarhad Journal of Agriculture 6: 411-415.

25. Jawahar S, Vijayakumar D, Bommera R, et al. (2015) Effect of silixol granules on growth and yield of rice. Int J Curr Res Aca Rev 3: 168-174.

26. Singh A, Shivay YS (2016) Effect of summer green manuring crops and zinc fertilizer sources on productivity, Zn-uptake and economics of Basmati rice. Journal of Plant Nutrition 39: 204-218.

27. Slaton NA, Norman RJ, Wilson EC (2005) Effect of zinc sources and application time on zinc uptake and grain yield of flood-irrigated rice. Agronomy Journal 97: 272-278.

28. Shivay YS, Prasad R, Singh RK, et al. (2015) Relative efficiency of zinc-coated urea and soil and foliar application of zinc sulphate on yield, nitrogen, phosphorus, potassium, zinc and iron biofortification in grains and uptake by basmati rice (Oryza sativa L.). Journal of Agricultural Science 7: 161.

29. Prasad R, Shivay YS, Kumar D (2013) Zinc fertilization of cereals for increased production and alleviation of zinc malnutrition in India. Agricultural Research 2: 111-118. 
30. Wang YY, Wei YY, Dong LX, et al. (2014) Improved yield and Zn accumulation for rice grain by $\mathrm{Zn}$ fertilization and optimized water management. J Zhejiang Univ Sci B 15: 365-374.

31. Ghasal PC, Shivay YS, Pooniya V, et al. (2016) Zinc fertilization enhances growth and quality parameters of aromatic rice (Oryza sativa L.) varieties. Indian Journal of Plant Physiology 21: 323332.
32. Yadav Devideen, Shivay YS, Singh YV, et al. (2018) Yield attributes, yields and nutrient uptake of Basmati rice (Oryza sativa) as influenced by in-situ and ex-situ green manuring crops and zinc fertilization. Indian Journal of Agricultural Sciences 88: 671678.

DOI: $10.36959 / 973 / 424$

Copyright: (c) 2020 Singh V, et al. This is an open-access article distributed under the terms of the Creative Commons Attribution License, which permits unrestricted use, distribution, and reproduction in any medium, provided the original author and source are credited. 